\title{
Anthropology of Experience: Touring the Past at Robben Island
}

\author{
Maheshvari Naidu \\ School of Social Sciences, University of KwaZulu-Natal, Private Bag X54001, \\ Durban, South Africa \\ E-mail: naiduu@ukzn.ac.za
}

KEYWORDS Experience. Liminal. Memory. History. Narrative. Relive

\begin{abstract}
This paper has a transdisciplinary orientation and is located in both anthropology and tourism studies. It draws on the seminal theoretical work of the post structural anthropologist Victor Turner and brings to the study of tourism, the concepts of performance, memory and 'experience'. The paper focuses on what the world has come to know as the place of incarceration for Nelson Mandela, and now declared a World Heritage Site and museum, established as the blurb goes, 'as a poignant reminder to the newly democratic South Africa of the price paid for freedom'. The paper looks at the construction of the site of Robben Island Prison Museum, in Cape Town South Africa as a performance space for the reliving and experiencing of a collective shared past and history and probes how visitors to the site, experience the space. Methodologically the paper uses narrative analysis of tourists' sharing stories of their visits in small focus type groups and in one-on-one interviews. It also draws on a thematic analysis of the visitor entries in a Visitors Book spanning a six month period of visits. The paper attempts to show that the site and constructed heritage product (or tour), emerges as a 'liminal space' where different racial categories of visitors, who have had differently shaped life histories, might be made to 'experience' a shared past of denial and oppression. Liminality speaks to a dislocation of structure and hierarchies, and by drawing on the ethnographic interviews of a randomised sample group of local and international visitors to the site, the paper shows that the visitor is placed into a liminal space by the manner in which the tour space is constructed and experienced.
\end{abstract}

\section{INTRODUCTION: ROBBENISLAND}

Robben Island, situated $8 \mathrm{~km}$ from the mainland off the coast of Cape Town, or Mother City as it is affectionately known, is unmistakably etched into the horizon and 'visible' in more ways than one to the local, as well as visiting eye. It is one of those sites that is, at once poignant and powerfully evocative of a painful past. Hoelscher and Alderman (2004:349) very rightly assert that "few places are as electrified with symbolic power and political contestation as Robben Island." The declaration of Robben Island, a former prison site to the status of National and then UNESCO Heritage Site is thus a profound recognition of the political and cultural potency of the site.

In 1997, the newly established Robben Island Museum Council mandated the Museum to pursue the following basic operational tenets as its main functions:

- To maintain the political and universal symbolism of Robben Island

- To promote Robben Island as a platform for critical debate and life-long learning

- To manage the Robben Island Museum in a manner that promotes economic sustainability and development
- To conserve and manage Robben Island's diverse natural and cultural resources in an integrated manner ${ }^{1}$

The last tenet focuses a curatorship eye on both the natural and cultural resources. And many of the cultural custodians ${ }^{2}$ at the museum are at pains to point out to researchers like me that the cultural as well as the natural resources on Robben Island were "both integrated into the Museum's activities and management plans'. This is borne out by information on the official Museum website which lists an archived stock of documents. These various publications and report documents in turn, sketch the contours of the development of the site from prison to museum, and take us back to the inception of discussions around 'how best' to showcase the Island and include reports about both the cultural and ecological resources offered by the Island.

Makhurane (2004) points out that the baseline studies for the State of the Environment Report in 2002/2003 included:

- a tourism impact study

- aerial photographs

- geological and geo-hydrological investigations

- vegetation survey and rehabilitation study 
- terrestrial vertebrates survey

- archaeological survey

- marine ecology survey

- building conservation survey

The bulleted list above thus attests to the host of experts (from a spectrum of disciplinary domains) that would necessarily have been involved in the various surveys. Likewise tourism studies about Robben Island can be located in any number of disciplinary and sub-disciplinary discourses and intellectual scrutiny; geographical, conservational, ecological, geological, cultural, etc. However, for me it is an anthropological gaze with its methodological praxis of participant observation and narrative analysis that is able to offer considered and nuanced scrutiny that attempts to speak to the unique cultural potency of the site as experienced by the visitors there. For Robben Island, like other sites associated with powerful events moored in history, offers a spatial location and 'spatial 'fixing' for the past that can be in a sense, revisited and relived and re-experienced. It was the ethnographer and anthropologist, Nathan Wachtel (1986: 216), who said that "the preservation of recollections rests on their anchorage in space". This is very true for Robben Island, for even though it has served (in various points in its history), as a military base, leper colony and hospital for the chronically ill, it remains most potently, the anchorage for the preservation of a cluster of political and cultural national recollections around denial and resistance.

\section{METHODOLOGY}

The study is located in a qualitative paradigm as, like most social anthropologists one believes that it is in the study of the lived archive of realities (Appadurai 1996) that one is able to discern the constructed realities of the participants in the study. To this end the study used face to face interviews (one on one or in small groups) with a randomly sampled group of adult male and female tourists to Robben Island, comprising both local South African, as well as international visitors over a period of three months January-April 2012 across three visits, in February, March, April and a fourth follow up visit in June/July 2012. Many of these participants were initially interviewed on the thirty five minute ferry trip from the Island. Several of these tourists were then invited to continue the con- versation once docking at the waterfront, over a cup of coffee, needed either to warm us up after the ferry ride back in brisk breeze, or for some unfortunate few, to steady the stomach after ferry induced queasiness. This manner of identifying and striking up quick rapport worked very well, especially amongst the people who were already touring in groups and had some 'free' time immediately after their scheduled visit to the Island. The manager at the Interpretive Centre was also able to assist in introducing me to people alighting from the ferry, whom he had met earlier as they had approached him for information about the Museum exhibits.

As it was not an overt aim to assess tourist expectations against tourist perceptions, the tourists were not interviewed on the way to the Island. This was deliberate. As the intention was to participate on the tour alongside the other tourists on each occasion, there was no wish to alert them to the fact that there was interest in their perceptions and experiences of the site. It was important to not make the tourists uncomfortable thinking that their perceptions and responses had to be rehearsed or 'role-played' for the benefit of the researcher on the tour with them.

It needs to be iterated that doing ethnographic work with any category of visitors to any kind of visitor site is notoriously difficult as it seemingly flies in the face of what the "ethnographic approach' means in the conventional sense (for the anthropologist that is). Ethnographic work is meant to be sustained and is meant to be repeated contact with the (same) participant over a meaningfully significant period of time. This is of course not possible with tourists as their visits to a site are usually fleeting, scheduled and once off. Given this, the anthropologist working in tourism studies, has to be more flexible in how data is gathered, and an attempt was thus made to 'act as tourist' at Robben Island over multiple times, over multiple visits which, although not offering a meeting with the same participant, did offer many instances and opportunities for participant observation and interaction with the tourists as well as tour space. Over the course of four research trips to Robben Island over January to July 2012, I went on approximately 24 tours of the prison Museum on the Island. Sometimes staying for the entire day on the Island and taking the tours back to back. As many different buses (each with its own guide) trans- 
ported the large numbers of daily visitors arriving on the ferries, in most instances I would be with both a different bus tour guide and different prison tour guide on the back to back tours.

Additionally, on all four visits, the researcher stayed at a popular tourist hotel a stone's throw away from the Victoria and Alfred Waterfront and the Robben Island Interpretative Centre which is also the point of departure for the ferry to the Island. There was thus opportunistic access to many foreign tourist groups that stayed overnight at the hotel and thus was able to speak with many of these tourists as well as tour operators frequenting the hotel and the concierge who was frequently called upon to offer tour advice to places like Robben Island. The various categories of staff at the Interpretive centre as well as those working on the island were also interviewed. There were thus a substantial number of individuals who were interviewed and form a secondary layer of participants, although primary responses are drawn from the total of 110 tourists comprising the tourists returning on ferries from the Island. The Visitor's Book at the Nelson Mandela Interpretive Centre as well as the Exhibitions there, together with the tour narrative and actual tour structure also form 'texts' that inform the study.

This study did not pay overt attention to tourist motivation as such. In other words it did not query why the tourists wished to visit Robben Island. Indeed interaction with many of the informants revealed that their motivations were hugely varied. Many knew that they "simply had to" visit Robben Island on this visit to South African and Cape Town and it held special significance given their own political beliefs and their knowledge of the country's past, and many wished to 'see' the place of incarceration of their beloved icon of peace, Mandela. Others had 'fallen in step' with the itinerary of their touring group, or taken the advice of fellow tourists. Many had, in typical touristic behaviour, 'marked' Robben Island as one of the many tourist attractions on their list. However, while it is of course conceded that tourist motivation and expectation is in many ways 'tied' to tourist experience, this research was not concerned with how they got there, or their motivations and expectations, but rather how they experienced the place, once there. In other words the study took as a starting point that the motivations were varied and proceeded to look at how different categories of tourists, with differently shaped expectations, appeared to experience the site.

The tour, whilst on the island is itself tightly structured and comprises choreographed movements from one point to another beginning at the point the ferry lands on the Island. At the point of arrival, island tour busses are immediately boarded and all visitors are offered a 45 minute guided tour of the Island, leading organically to the meeting point of the next guide and walk through-tour of the various prison blocks and cells. From there it is on to the short stopover at the gift shop and eventual boarding on the returning ferry back to the mainland. There is no time for socialising or talk amongst the tourists as they take up their 'positions' and listen attentively to the narratives of the guide on the bus, who points out and explains various features of significance on the island. $\mathrm{He} / \mathrm{she}$ introduces us to the guide meeting us at the entrance to the prison, whose narrative aims for a kind of 'reliving' of various instances of the prisoners' lives.

\section{OBSERVATIONS AND DISCUSSION}

\section{Robben Island and Memory}

Makhurane who in her report at 2004 ICOM or at the conference of the International Council of Museums, where she presented her paper, although pointing out the many baseline investigations on which the Environment Report was erected, herself goes on to have written:

"In identifying the rich cultural heritage of the Island and its political significance as a place where the "human spirit triumphed over adversity", the conservation and interpretative strategies that have been developed have focused on intangible heritage, which is encompassed in memory and oral tradition and therefore contributes to the development of a site of living memory" (Makhurane 2003: 4).

Makhurane was a staff member at Robben Island Museum and worked here for several years so she speaks from intimate and sustained relationship to the actual space as well as to many of the policy and management discussions that sought to shape the tourist experiences here. Having spelled out the various natural resource indices against which the Island is discussed, it is to the intangible heritage, best revisited through memory, and best reactualised through memorialisation, that she returns. 
Other South African academics, Rasool (2000) and Coombes (2003) have written about Robben Island and re-memorialisation in the context of South African nation-building, remembering and reconciling. American scholars Hoelscher and Alderman (2004: 349) writing about Robben Island, tell us that the site brings to the fore several central themes. They summarise these as:

1. the continually unfolding nature of memory;

2. the importance of forgetting in every act of remembering;

3. the pressures of the marketplace and commodification of the past;

4. the fact that memory is often both particular and universal;

5. the inextricable link between memory and place

Both South African scholars acknowledge the importance of memory, remembering and forgetting. Memory also features overtly in four out the five themes that American scholars Hoelscher and Alderman have identified, as does it in Makhurane's description of how she articulated her work on the Island.

Thus memory emerges as a powerful theoretical leitmotif. According to Halbwachs (1992: 45), what makes memories collective, are the social environments of memory, such as (verbal) language and social convention, which also work as mechanisms of social pressure Thus a sociological and constructivist approach to memory and frames of remembrance, regards it as dynamic, created, and as a potential source of social contests. Strange and Kempa (2003: 389), in writing about penal institutions turned heritage spaces, write that once prisons "shed their penal functions for new touristic identities", their historic relevance comes to be interpreted (or reinterpreted one adds) within what he refers to as "nationally distinct and dynamic cultures of memorialisation." While of course 'memory' work can be explored in and from multi-disciplinary perspectives, I approach memory from an anthropological perspective in the context of performance and tourism product construction, as shaped and experienced at Robben Island.

\section{Anthropology and Tourism/ Anthropology of Tourism}

It is of course well documented by now that the study of tourism is decidedly interdiscipli- nary. Indeed I write this paper in the wake of just returning from an international biennial conference on Tourism Studies hosted by the Anatolian Journal that had in the last two conference meetings (2010 and 2012) added to their longstanding conference on Tourism Studies, a parallel conference entitled "Interdisciplinary Conference on Tourism Studies" attended by anthropologists, sociologists, geographers etc. The Plenary session saw John Urry (2012) and Jafar Jafari (2012) speak to what they understood to be the interdisciplinary and transdisciplinary perspectives of Tourism studies. That said, there is nevertheless, the necessity to signify the defining features for claiming to locate the study within an anthropological discourse. This is because there is one stream of intellectual opinion that there is no sustained and discernible body of work that warrants the recognition of a subdiscipline of 'Anthropology of tourism'. In describing their position and offering a kind of literature survey of the canvas of work by anthropologists, Naomi Leite and Nelson Graburn (Leite and Graburn 2009) label their chapter, rather interestingly as 'Anthropological Interventions'. As someone who teaches in Anthropology, 'interventions' for me, is evocative of an activistic and advocacy stance, an applied anthropological concern, and I am uncomfortable with that as, what the chapter is in fact, is a description of the various studies from and within anthropology, (applied and academic) where issues of 'culture', notions of heritage, identity, 'ethnicity' etc. are examined. There are additionally the large anthology edited by Valene Smith (the classic collection of papers entitled Hosts and Guest in Smith 1989) and that of Dennison Nash (1996) that have both located and titled their works as 'Anthropology of Tourism'.

However, I do concede the point that there appears to be an absence of a visible cohesive body of literature that accretes together recognizably, to present a singular 'intellectual face' of an Anthropology of Tourism. However, this concession comes with a caveat as there are nonetheless distinct works that can safely be seen as anthropological work in tourism studies. Notwithstanding the apparent absence of a cohesive spinal sub-disciplinary body of work in Anthropology of tourism, the paper is located in large part, in anthropology and draws on the seminal theoretical work of the post structuralist anthropologist Victor Turner, and brings to 
the study of tourism, the concepts of performance, and most importantly, memory and 'experience'. Indeed it was Victor Turner who said back in 1987; "For years I have dreamed of a liberated anthropology” (Turner 1987: 3). For me such a 'liberated anthropology' has 'porous edges' and is an active participant in interdisciplinary or transdisciplinary work.

For Turner, the climate back in the late eighties was one in which, to use his own words "academic disciplines had clearly defined boundaries which one transgressed at one's peril." He refers to the other highly noted anthropologist, for her work on pollution and boundary maintenance, Mary Douglas, and tells us that interdisciplinary work (in anthropology) during that period was seen as a form of pollution, and an "abomination" (Turner 1987: 3). Fortunately the intellectual climate of inter-disciplinary and transdisciplinary work has shifted direction and the ice has thawed so to speak and there are many contact points between anthropology and disciplines such as tourism studies.

It is also by now, well accepted and clearly discerned that there is much that can be understood in tourism and the construction of tourism products, as performance and theatre. There are the various elements of theatre in the form of the actors or individuals that work at the tourist site, the staging, the design elements constructed for consumption, and of course the assembling of the various elements of the experience itself, more often than not assembled to be memorable, evocative and to able to leave some indelible imprint on the audience, the gazing tourist. The argument put forward is that the Robben Island Tour experience is best understood as performance and best grasped by proceeding through the heuristic device of the 'liminal'. The word 'liminal', was originally coined in French by Arnold von Gennep in 1909. 'Liminal' features fairly popularly in the current lexicon of anthropology, yet only gained popular purchase in the 1960s when much of Gennep's work was translated into English (Van Gennep 1960) and many of his theoretical concepts, like' liminal' was adapted by Victor Turner (Turner 1967) for his analysis of the African Ndembu rituals. Liminal' as a "sociological useful concept" (Wels et al. 2011) refers to an in-betwixt state, of neither here nor there, the middle phase or state of a ritual where there is usually a three-fold transition from stage 1 (social being as is) to stage three (new social being). One common and rather popularly used example would be the ritual initiation of a young Zulu, from 'boy' into 'man'. The liminal state in this example would be the, middle state of being neither 'boy' nor 'man' but a suspended threshold in-between state, when the young Zulu is no longer a boy, but not yet a man, in social terms that is.

Drawing on the several interviews with the visitors on the ferries returning from the Island Tour as well as the interviews with the touring groups that stayed at the hotel I was based at, I argue that the Robben Island Experience allows the visiting tourist (both international as well as South Africans from other parts of the country) to likewise temporarily suspend their individual past, and to share in the past of the prison inmates at the Museum and the South African Apartheid past. In this short period of liminal state, they are neither, local or international tourist, (whom they would have arrived as) neither are they the political prisoner (whose space of incarceration they are visiting), but on the threshold, and suspended in an in-between state that allows them to share a communal experience which peels off an individual past by offering the memory of a shared history.

\section{Performing Memory and the Past}

Performance as an anthropological notion traces back to the 1970s where performance comes to be viewed as a lens to examine and interrogate social processes and social organisation, and cultural performance comes to be seen as offering a "frame that invites critical reflection on communicative processes" (Bauman 1990). Some anthropologists have shown how performance is a mode of performed resistance or a way to critique postcolonial structures of power and domination (Bruner 1994). The rich protest theatre during the Apartheid era, much of which emanated from the vociferously resistant University drama centres such as the old University of Durban-Westville, or UDW (now merged into the larger body of the University of KwaZulu-Natal, or UKZN) is a case in point. However, performance as a refractive lens also allows post-structural understandings of the theatrical stagings and performance of memory, identity and heritage.

This performative 'turn' is best explained by understanding that for anthropologists like Vic- 
tor Turner (1987) who worked with ritual and memory and experience, this heralded a paradigmatic shift from structure to process. Emphasizing process contributes a sense of agency that was difficult to discern in structural ideas of culture and moves the study from texts 'to texts in context' (Lamberth 2003) Lamberth goes on to add that "a new emphasis on performance directed attention away from study of the formal patterning and symbolic content of texts" to the emergence of the verbal "in the social interaction between performers and audiences" (Bauman 1990). This shift is exemplified by the change in terms from text to entextualization and from context to contextualization (Bauman 1990). Performance can best be understood as any behaviour that is 'twice-behaved' or 'restored' (Schechner 2002: 5) This allows a point of insertion for viewing the constructed touristic experience at Robben Island to be read within the repertoire of 'performance' as we look to see what is being performed and inscribed, and more importantly for this study, how it is being experienced.

\section{Experiencing Memory and the Past}

Having visited ${ }^{3}$ Robben Island as a researcher (and tourist) it becomes apparent that the construction glue employed in the 'production' and staging of the tourist experience that seeks to hold the experience together is 'memory' as social memory, cultural memory, and political memory. This memory is 'performed' through the rich narrative offered by the guides (themselves former political prisoners at the prison) and through the walk-through tour of the prison. The memory is performed and restaged for the visitor by the narrative of the tour guide as he walks and 'talks' the visitor through particular spaces of the prison.

This assertion is reinforced by the many of the visitor perceptions shared by the people visiting and touring Robben Island as well as by a thematic analysis of the 2012 entries in the Robben Island Interpretive Centre Visitor Book. The entries from just the beginning of the year, $1^{\text {st }}$ January to $30^{\text {th }}$ June 2012 , span over 1325 entries. This is of course not a full representation ${ }^{4}$ of the visitors to the Centre and Robben Island, as not all the visitors choose to leave an entry in the book. It is however, an extremely rich source of information as all the entries are voluntary and not solicited in any way. Indeed the visitor book sits rather unobtrusively on one of the tables and the table itself doubles up as a museum fixture that houses exhibit documents in the table drawers. The first time I visited, I had almost mistook the book for an exhibit, as it even looked similar to other books with archived prison entries, placed elsewhere in the museum.

While many entries had full details of date and name and nationality of the person making the entry and visitor comments, a substantial number did not have dates and full name or country details. I have chosen to site the examples of only those entries that display national status as this was of course a vital variable in understanding who (from where) was saying what. It was deemed less important if the dates or their names were omitted as this did not detract from the import of what the visitor was saying. Below are a sample of eighteen entries across a six month period that offer an insight into how the Robben Island Tour and Interpretive Centre exhibits were experienced by South African and international visitors ${ }^{5}$. Nine examples are culled from the local entries and nine from the international tourists visiting.

- It is so fascinating to see so many things from the past here. It is a real pleasure to be a South African. We love you Mandela. God Bless. M Ismail from Twsane

- Viva South Africa! A South African

- 9/1/2012 - Very emotional and a remarkable experience of world history. We love it! Thank you! George and Patricia Douglas from Britain

- 9/1/2012 - I enjoyed the experience. I learnt so many things about my past that I knew but had forgotten. South African

- Lovely place to reflect what has happened in the past. We need places like this to remind us all...Touching stories! We are from England

- So pleased to visit our history again with my friends. Cape Town and friends from $\mathbf{K Z N}$

- We thank you for this, to help us remember the past. Delhi, India

- It is like a "time capsule". Very emotional! Greg and Tanya-America

- What a sad situation it was then. 'On Holiday from Durban'

- $5 / 2 / 2012-$ What a truly great honour it is to visit this place. This place reminds me 
that there are many selfless people, who can give their lives for others to live a better life. The past affects us all. We are all one. South Africa's past is our past. D Portman-American.

- This is the place that I have been longing to visit for a long time. It reminds us that the world is one family. It is like visiting my pain. Wayne and Lesley from Channel Islands UK.

- We thank you for this to remember the past. Sometimes we forget we are all human, so we need this place. Nelspruit

- $\quad 15$ /4/2012- I learned real stories from my visit to Robben Island. I apologise for my ignorance. Lesley Morgan British by birth, South African by choice.

- If history can be erased, this is one part that I would never want to erase. This must be one history that must be taught to the children. S. Gounden Durban

- Fuck you apartheid!!! Stay in the past! KwaZulu-Natal

- A very informative way of informing us of the past! : Carol Brown and Alan Lawson Scotland

- 16/06/2012- First time to Cape Town.... Madiba's story is inspiring to all. Finland

- Very informative! And evocative of our own History... Germany

These examples reveal a sustained pattern running through the entries (January 212-June 2012) that spoke to the visitors' experience of acknowledgement and in many cases intense appreciation of a past that they could identify with, even if they were not themselves South African. Although I did not have any opportunity for a similar in depth analysis of the other Visitor Books from previous years, as these formed part of the locked archives of the Centre and would have demanded many hours warranting a study on its own, I did manage to elicit a perusal of five other books from 2011, 2008, 2007, 2006, 2009 thanks in large part to one of the staff that brought these to me. A cursory scan of the books also revealed many local and international entries liberally peppering all the books with entries of being able to 'relive' and 'go back to' the 'past'.

While a scrutiny and thematic analysis of the comments by tourists in the Visitor books allowed me to read and 'see' how the visitors framed their experience of Robben Island, the one on one interviews with the returning tourists on the ferries and in the hotel gave more intimate insight into how they had experienced the visit and tour at Robben Island, and offer grist for narrative analysis.

Narrative analysis views narratives as interpretive devices through which people represent themselves and their worlds, to themselves and to others. Narrative inquiry is the interdisciplinary study of the activities involved in generating and analyzing stories (or 'scripts') of life experiences through interviews, journals or memoirs (Schwandt 2007: 204). Scripts are the referential core of personal narratives and the analytical frames from which particular behaviour is interpreted culturally (Labov and Waletzky 1997). This form of qualitative scrutiny is also particularly apposite given that much of what we as researchers receive in interview accounts, are likely to be 'storied,' in other words received in narrative form. Also with this technique, in most instances the researcher says very little, acting primarily as an attentive listener, which was especially suited as some of the informants were very eager to share what they felt to be a profound experience.

Stories themselves of course are fluid and shifting, and 'shift and change in their 'telling' and are different from an individual to another. However, repeated storylines amongst different 'tellers' offer thematic issues for scrutiny. Using narrative analysis, I could see that particular themes or scripts emerge in the stories that the visitors 'told.' Perhaps understandably, many of the local South Africans referred to a sense of collective history, or "shared past". However, just as interestingly, many international visitors also appeared to have been put into a space where there were able to step into a past that was not their own. Many of these visitors were also visibly moved as they spoke to me.

Dan Gopaul told me that,

... although Black Africans suffered the most, other race groups were also treated in inhuman ways. This is our history...many Indian comrades were at Robben Island at the same time as Nelson Mandela.

Mary, a forty two year old Caucasian who was on a pre-organised group tour of the main tourist arterial sites, what local tour operators would refer to as a 'classic tour' had completed the other legs of her itinerary and said she was thoroughly enjoying the final leg in Cape Town. 
She tells me that the visit to Robben Island touched her in ways that she could not have imagined;

I knew of Robben Island of course and was very happy that the group was scheduled to visit... but I can't get over how moved I felt when I actually got there...walking through those prison cells...it was like walking through history...it did not matter that I myself am not South Africa.. I felt that this was my history too... it was my pain too...

Another member of Mary's group, an American Italian, fifty-five year old Antonio, who had been living in the States for the last five years shares in halting English;

Ifelt very close to everybody in the group...I already knew everybody...they are travelling friends, but we were very close in that moment and I felt very close to the people of South Africa...we all know what it is to suffer in one's own land...it was powerful to hear the tour guide...the way he showed us everything...he made me feel like I was there..

During the liminal stage, normally accepted differences between the participants, such as social class, are often de-emphasized or ignored. A social structure of communitas forms based on common humanity and equality rather than recognized differentiated social relations, and a kind of social homogeneity is created for that moment, and if only momentarily. Performances are events that have been constructed through a multi-stage process: they have prepared, and are then 'framed, presented, highlighted or displayed' in a heightened manner, all of which occurs during the tour as the tour guide on the bus and at the prison, goes through their prepared 'script' which frames various events in the political history of Robben Island and some of the well know prisoners who have been housed here. According to MacCannell (1999: 43), there are five stages of what he terms as sight sacralization (naming, framing, enshrinement, mechanical reproduction and social reproduction). All these stages form the performance cues in the construction of the tour experience capable of transforming the space into valuable cultural sight. The enshrinement stage has the potential to accomplish a transformation of liminoid tourists. A good example of this is the tiny cell that housed Nelson Mandela for many years. Although having the same spatial dimensions of all the other cells, the texture of this space was noticeable different judging from the expressions and demeanour of the tourists craning their necks outside in the corridor. For the tourist, it is an enshrined space, made all the more sacred by the 'relics' that still lie there seemingly untouched; Madiba's blanket and pillow, his bucket and his tea-cup and plate, all poignantly placed. The tourist is allowed a few seconds, as each in the group is allowed to move past in single file 6 . For many the whole point of wanting to visit the island was because of the meaning of this one cell. For Turner (1987: 4) 'actions' are capable of assuming a 'performed-for-an-audience' aspect. The tour guide in this instance, 'performs' and narrates a selected repertoire of details as he points to the live 'diorama', or the tiny cell with Mandela's historic relics, all of which have been appropriately costumed with memory, and invoke in the audience a particular range of emotions as they churn up issues of oppression and subjugation and injustice. The group is treated as 'one being', and even appear to articulate themselves as 'one', judging from their expressions and from some of the comments of the participants interviewed. Such situations are described as anti-structural reversals of everyday routine existence, during which the normal social and other differences among the tourists are temporarily suspended. Normative divisions amongst the visitors in the group or amongst the various visitors stopping to make an entry in the visitor book are abandoned, and for the tourists in the group tour, a sense of oneness or collective feeling resembling communitas ${ }^{7}$ was created and experienced.

Richard Schechner (2002) outlines seven functions of performance;

- To mark or change identity

- To teach, persuade or convince

- Toheal

- To make or foster community

- To entertain

- To make something that is beautiful

- To deal with the sacred and/or the demonic It appears that at the Robben Island Museum, many of these functions are actualised. There is a concerted effort in the manner in which the construction of the website, the exhibitions in the Interpretive Centre and the tour guides' narrative is constructed to teach and be educative about the political past of South Africa. It draws attention to both the social atrocity and the injustice of a shared past and history as well 
as a reconciliatory present and future by working to foster a 'community' among the visitors to come to visit. The accent is on healing and reconciliation (see also Strange and Kempa 2003). Indeed the last part of the narrative by the prison tour guides is invariably delivered in a large and evocative voice and makes reference to moving out of hatred and into justice for all and includes the ubiquitous slogan of 'rainbow nation'. The narrative even invites you to leave (the tourist site of the prison) 'changed' and 'free'. These words are somewhat 'cheesy' but also oddly suited and able to point from a common past to a common future. In as much as the visitor is entertained, s/he has been shown something that is both demonic and beautiful (the unjust past and the promise of a just future). While the heritage product or tour may not have been consciously constructed to enact Richard Schechner's description of what performance does or should do, it nevertheless works beautifully in fulfilling Schechner's tenets for the functions of performance.

Entextualization describes the process that makes text into a coherent unit (Bauman 1990) and performance comes to inseparable from its context. With the processes of entextualization and contextualization, ethnographies of performance have uncovered the dialogue between what is said and the cultural context in which it occurs and these cultural performances are said to be marked by performers and audiences interacting in a finite body of time (Singer 1972). This finite body of time is the time marked by the tour itself, although the tour at Robben Island is a kind of palimpsest, with the tour and performance operating at many temporal and spatial points and layerings (embarking on ferry to Island, getting on the bus tour and going around the island, getting off the bus and beginning the prison tour with a new guide as well as touring the Museum and Interpretive Centre either before getting on the ferry, or after returning from the ferry). The narrative is likewise performed on multiple levels, embedded in multiple points, at the Interpretive Centre, bus and prison.

\section{CONCLUSION}

Why is it important how tourism products are constructed and performed? Well, embedded in the question are signposts to the answer. How these products are assembled and per- formed for an audience of tourists and how these products are experienced is vital for the simple fact that the world is increasingly rendered mobile and portable in a touristic sense with both tourists (and their money) criss-crossing the globe and geographic (and cultural) spatial coordinates. Moreover quite often tourist products (such as the Robben Island Tour) attempt to offer a master narrative of national heritage and identity. What the products perform to an audience and how the audience 'experiences' these are important in allowing us to understand what 'face' we are offering up to the global tourist market.

At Robben Island memory and the past is reconstructed and performed in a touristic product that is evocative of a shared heritage and a shared collective future. Social memory, nation building and heritage tourism have been in the center of debates in South Africa in the last few years, and draws our attention to the fact that instances of cultural and heritage tourism are often used as vehicles for a national narrative. Indeed even the very website of Robben Island website declares:

"Since 1997 it has been a museum and a heritage site. The museum is a dynamic institution, which acts as a focal point of South African heritage."

Source: Robben Island Interpretive Museum webpage.

\section{NOTES}

1. All these points are on the Robben Island Heritage website and were reinforced in the meetings with the Heritage manager, Richard, on my visit to the Interpretive Centre and Museum

2 . This is a personal communication with the one of the 'Activities Director' at the Museum.

3. While it was the overt intention of the study, taking multiple tours also gave rich insight as to how different tour guides each contributed to uniquely shaping the experience at the Island through particular idiosyncrasies in their narrative delivery. What I draw on rather, is the common spinal backbone of their role in performing the prison experience for the visitor.

4. By 2001 alone the visitor number at Robben Island had reached its 1 millionth mark according to the activities manager at the Interpretive Site.

5. Only entries from visitors who had taken the actual tour onto Robben Island, as opposed to the odd visitor who came only to visit the Interpretive Centre were selected in the examples. It was also a small number, less than ten from the 1325 visitors, who only visited the Centre. This was clear from how they worded their entries, in other words it 
was feedback on how they experienced the interpretive site.

6. I was reminded of a trip I took many years ago to a site perceived as holy within the South Asian tradition. After the assent of many hundreds of stairs and many hours spent in a queue that snaked several kilometres, one at last got a glimpse of the Deity in the inner sanctum of the shrine. Due to the large numbers of people behind one, the moment in front of the deity was but a fleeting few seconds, but the experience was one of heightened intensity.

7. Makhurane draws our attention to the interpretive concept of 'pilgrimage' (2005: 3 ). She goes on to say that "each site for the presentation of Robben Island's message becomes a stage in the pilgrimage" and that "this process of transformation constitutes the historical event that visitors come to "experience', see, find and celebrate". So for Makhurane, from a managerial and curatorial perspective, the tour and island as heritage products are constructed as spaces to experience a pilgrimage. However, none of the participants referred to their visit as a pilgrimage, although they used words such as 'profound' and 'enlightening'. And although aware of course that to ask a direct question points to a methodological faux pax, even this rather dubious line of questioning did not illicit stories about an "enlightened journey", but rather that they were enlightened by what they experienced.

\section{REFERENCES}

Appadurai Arjun 1996. Modernity at Large: Cultural Dimensions of Globalization. University of Minnesota Press/Minneapolis: London.

Bruner Edward M, Barbara Kirshenblatt-Gimblett 1994. Maasai on the lawn: Tourist realism in East Africa. Cultural Anthropology, 9(4): 435: 470.

Bauman Richard, Charles Briggs 1990. Poetics and performance as critical perspectives on language and social life. Annual Review of Anthropology, 19: 59-88.

Cohen Eric 1988. Traditions in the qualitative sociology of tourism. Annals of Tourism Research, 15: 29-46.

Coombes AE 2004. History after Apartheid: Visual Culture and Public Memory in Democratic South Africa. Johannesburg: Wits University Press

Halbwachs M 1992. On Collective Memory. Chicago, London: University of Chicago Press.

Hoelscher Steven, Alderman Derek H 2004. Memory and place: Geographies of a critical relationship. Social and Cultural Geography, 5(3): 347-355.

Home Page for Robben Island Interpretive Centre and Museum. From < http: //www.robben-island.org.za/ index.php? option $=$ com $_{-}$contentandview $=$articleandid=9 andItemid=9>. (Retrieved on 1 February 2010).

Labov W, Waletzky J 1997. Narrative analysis: Oral version of personal experience. Journal of Narrative and Life History, 7(1-4): 3-38.
Lamberth S 2003. From <http: //www.indiana.edu/ wanthro/theory_pages/performance.htm> (Retrieved February 2012).

Leite Naomi, Graburn Nelson 2009. Anthropological interventions in tourism studies. In: Tazim Jamal, Mike Robinson (Eds.): The Sage Handbook of Tourism Studies. London: Sage Publications, pp. 35-64.

MacCannell D 1999. The Tourist: A New Theory of the Leisure Class. Berkeley and Los Angeles: University of California Press.

Makhurane Juanita 2003. Robben Island - Developing an Integrated Environmental and Heritage Management System. In: 14th ICOMOS General Assembly and International Symposium: 'Place, Memory, Meaning: Preserving Intangible Values in Monuments and Sites', 27 - 31 Oct 2003, Victoria Falls, Zimbabwe. From <http://www .international. icomos.org/victoriafalls2003/papers/C2-1 - Pastor.pdf> (Retrieved on 5 March 2012).

Nash Dennison, Smith Valene L 1991. Anthropology and tourism. Annals of Tourism Research, 18: 1225.

Nash Dennison 1996. Anthropology of Tourism. Oxford, United Kingdom: Pergamon Press.

Rassool C 2000. The rise of heritage and the reconstitution of history in South Africa. In: R Field, D Bunn (Eds.): Trauma and Topography: Proceedings of the Second Colloquium of Landscape and Memory Project. Johannesburg: University of the Witwatersrand, pp. 1-21.

Singer Milton 1972. When a Great Tradition Modernizes: An Anthropological Approach to Modern Civilization. New York, Washington, London: Praeger Publishers.

Smith Valene 1989. Hosts and Guests. USA: University of Pennsylvania Press.

Stoller Paul 1997. Sensuous Scholarship. Philadelphia: University of Pennsylvania Press.

Schechner Richard 1985. Between Theater and Anthropology. Philadelphia: University of Pennsylvania Press.

Schechner Richard 2002. Foreword: Fundamentals of performance studies. In: Nathan Stucky, Cynthia Wimmer (Eds.): Teaching Performance Studies. Illinois: Southern Illinois University Press.

Schwandt T A 2007. The Sage Dictionary of Qualitative Inquiry. $3^{\text {rd }}$ Edition. Thousand Oaks, CA: Sage Publications.

Strange C, Kempa M 2003. Shades of dark tourism. Annals of Tourism Research, 30(2): 386-405.

Turner Victor 1967. The Forest of Symbols: Aspects of Ndembu Ritual. Ithaca and London: Cornell University Press.

Turner Victor 1987. The Anthropology of Performance. New York: PAJ Publications.

Van Gennep A 1960. The Rites of Passage. USA: The University of Chicago Press.

Wachtel N 1986. Memory and history: Introduction. History and Anthropology, 12: 207-224.

Wels Harry, van der Waal Kees, Spiegel Andrew, Kamsteeg Frans 2011. Victor Turner and Liminality: An introduction. Anthropology Southern Africa, 34(172): 1-5. 